\title{
Custody and Care of Children in Spain: Can the Two Rights be Reconciled?
}

\section{Marcela Jabbaz Churba ${ }^{1}$ (i)}

Accepted: 18 May 2021 / Published online: 17 July 2021

(c) The Author(s) 2021

\begin{abstract}
This study aims to analyse the legal decision-making process in the Community of Valencia (Spain) regarding contentious divorces particularly with respect to parental authority (patria potestas), custody and visiting arrangements for children, and the opinions of mothers and fathers on the impact these judicial measures have had on their lives. It also considers the biases in these decisions produced by privileging the rights of the adults over those of the children. Three particular moments are studied: (1) the situation before the break-up, focusing on the invisible gender gap in care; (2) the judicial process, where we observe the impact of hidden gender-based violence and gender stereotypes; and (3) the situation post-decision, showing how any existing violence continues after divorce, by means of parental authority. The concept of 'motherhood under threat' is placed at the centre of these issues, where children's voices are given the least attention.
\end{abstract}

Keywords Child's best interests · Child arrangements · Family law · Gender-based violence $\cdot$ Joint custody $\cdot$ Residence orders

\section{Introduction}

In 2005, a reform of the civil code at the national level in Spain incorporated important changes in the area of divorce. One of these was a new legal form of custody called 'custodia compartida' (joint custody) when requested by both parties and, in exceptional cases, when requested by only one of the parties, on the condition that two criteria are fulfilled: a prior favourable report from the Public Prosecutor's Office (art 92.8), and that this is the only way for the child's best interests to be adequately protected (art 92.8). This rule has been controversial (Picontó Novales 2010; Cruz Gallardo 2012; Salas Carceller 2020), in part because of its exceptional nature; thus Alascio Carrasco (2011) points out that the courts have to weigh this

Marcela Jabbaz Churba

Marcela.Jabbaz@uv.es

1 University Institute for Women's Studies, University of Valencia, Valencia, Spain 
rule on a case-by-case basis, and Campo Izquierdo (2009) questions the fact that the judge's jurisdictional function is limited by the existence of a favourable report from the Public Prosecutor's Office and with joint custody promoted as the preferred outcome. As shown in the data, over the last ten years the number of court decisions in favour of joint custody has increased significantly, marking a break from what had previously been the general rule of granting mothers sole custody as the best way to guarantee the well-being of children after a marriage is dissolved.

The legal changes may reflect other changes taking place in society in several dimensions, specifically in terms of the framework of thinking and social expectations related to fathers' involvement in care (Cozzolino and Williams 2017). But these transformations in the law and social expectations have not been accompanied by significant changes in shared parental responsibility in any objective way (Tobio 2012; Fernández Rasines 2016). In the cases investigated, divorced fathers, with one exception, did not substantially change their participation in caring for their children. The rise in joint custody is not, therefore, a consequence of a change in gender patterns (Gálvez Muñoz 2016). We have observed in the cases analysed through interviews that fathers are often nominal custodians, as they actually transfer care tasks to women in their family (new partners, grandmothers, sisters).

Joint custody would perhaps be the most desirable option if there were no gender inequalities and, if women and men peacefully agreed on custody and responsibilities. However, the real circumstances of the mothers and fathers studied here are quite different and this decision takes place in the midst of a high level of conflict, such that individuals are unable to resolve their own private conflict, and therefore resort to legal battles.

The study was carried out at the request of the regional government of Valencia as part of the Pacto Valenciano contra la Violencia de Género, Valencia's Pact against Gender-based Violence. ${ }^{1}$ Our university was asked to carry out a qualitative study to identify gender biases that occur in the legal decision-making process regarding parental authority (patria potestas), custody and visiting arrangements for children in the Valencian Community. ${ }^{2}$

The study's object was defined as the views of mothers and fathers in contentious divorces about the process of the courts' decisions on different custody arrangements and the impact that these judicial measures have had on their lives.

The thesis of this article is that custody is a subjective right or an attribute of adults recognised by law, while care is a subjective right of children, which is less

\footnotetext{
1 On 10 April 2017, the Valencian Government called on representatives of political parties, economic and social agents, universities, feminist organisations, women's survivor groups, the nonprofit sector, the media, the security forces, the judicial system and all branches of Valencian public administration to work on the Valencian Pact against gender-based and sexist violence. The Pact was signed on 18 September 2017 and was structured around 5 priorities, 21 objectives, and 293 measures aimed at eradicating violence against women. http://sinmaltrato.gva.es/es/pacte-valencia-contra-la-violencia-de-genere-imasclista. Accessed 18 June 2021.

2 This study is part of Priority 3 of the Pact entitled Coordinating Networks of Care for Women Victims of Gender-based and Sexist Violence and their Children, Measure 9. The research results were published in the report by Jabbaz Churba and Díaz Martínez (2020).
} 
valued in legal practice. Furthermore, when the case involves unreported genderbased violence, the court's decision does not enable calmer relations between the partners post-trial, but rather the conflict, coercion and threats continue through other channels. The abuser, in order to regain some of the status lost after the divorce, uses his right to parental authority and questions the mother's control over everyday micro-decisions related to their children, such as school activities, parties, schedules, doctor's visits, as well as host of other issues.

However, the relationship between custody and care is complex. On the one hand, the experts, whom we consulted in this research using the Delphi technique (Linstone and Turoff 2011), indicated that children need, in the first place, stable, clear and close links with their parents or at least one of them. The experts explain how relatives and close associates can provide care support but not replace this close, everyday parental role. However, when there is gender-based violence, contact with the father can be harmful and therefore, these situations cannot be addressed in a simple court decision. Rather, the institutional attention must be holistic, providing the children with an information service about their legal situation and the psychological support available. As Gaitán Muñoz (2018) points out, it is necessary to review the concept of being a minor and to enable children to exercise their rights and citizenship in a real way.

In our study, there were strongly rooted assumptions among the professionals, both legal and psychological, about the supposed need for custody to be shared in order to safeguard parental ties with children following the break-up. But even if its importance is assumed, why should joint custody be favoured when there are several possibilities? Contact with both parents can occur in various combinations and with varying degrees of intensity, better suited to family dynamics. There are many formulas: for example, exclusive custody could be granted to whomever has the willingness and time to care, with extensive contact arrangements for the other parent. That said, the importance of contact must not be overestimated with respect to care needs, especially when there is conflict (Gilmore 2006). It is also highly questionable for children to be forced to maintain contact with a parent when they do not want to, without any action on the part of the court to identify the source of their refusal. Moreover, Fehlberg et al. (2018) point out that family law has fallen into the error of assuming a concept of formal equality, trying to balance rights without understanding the different situations experienced by women, men and children in the process of separation.

In an ideal world, shared responsibility, and consequently joint custody, would be desirable because care would be directly carried out by both parents. However, oftentimes this is not the reality in contested divorce cases with real-world custody disputes.

\section{The Regulatory Framework}

The 2005 reform of the Spanish Civil Code introduced joint custody as a legal concept and opened up a controversy that still continues because it leaves many legal grey areas (Picontó Novales 2010; Cruz Gallardo 2012; Salas Carceller 
2020). One view favours greater use of joint custody as the preferred option, even when there is conflict between the former partners, arguing that it encourages shared parental responsibility and ensures continuity of the bonds with both parents after the seperation. The other considers that the courts should not automatically favour any residence or custody arrangements, but should work on a case-by-case basis, because of the possibility of unreported situations of gender-based violence.

The earliest debates revolved around the fact that the child's best interests were considered an 'indeterminate good', which would be clarified long afterwards in Law 26/2015 of 28 July, Modifying the System for Protecting Children and Adolescents. Children were included as direct victims of gender-based violence and their right to be informed, and heard was established. However, even now, the merits of this law have not been fully translated into legal practice. Faced with this situation, some autonomous communities-Catalonia, Valencia, Aragon, the Basque Country, and Navarre-promoted laws to 'solve' the problem of the ambiguity involved in interpreting the child's best interests. The laws established that joint custody was the preferred regime for post-divorce arrangements, even in situations of conflict between the ex-partners. In the Community of Valencia, Law 5/2011 of 1 April was passed On the Family Relations of Children Whose Parents Do Not Live Together, commonly known as Imposed Joint Custody, which, as explained by Judge José Conde Pumpido García (2011), has been the subject of heated social and legal controversy since being passed.

In 2013, the Supreme Court Ruling 495/2013 gave new impetus to joint custody and stated that "it should be considered normal and even desirable, because it allows the right of children to have a relationship with both parents to be effective, even in crisis situations, whenever possible".

Finally, in 2016, Valencia's Joint Custody Law was repealed by the Constitutional Court because the autonomous community did not have legal authority to establish such a law, which is the responsibility of the state. However, the substantive debate and the social and legal controversies continue to be very much alive.

In our research, we move away in part from the legal debate because we are interested in investigating how court decisions contain moral and ethical criteria when evaluating forms of post-divorce arrangements (Hacker 2008). In this context, judges and prosecutors may assign different importance to the psychological, material, educational and medical interests of children, and they may tend to value the present or prioritise the future. Additionally, there are studies that indicate that judicial reasoning is highly conditioned by judicial traditions (Hunter 2015) and that those who deviate from these rules face institutional resistance and being excluded themselves. Our interest is also directed towards what Gilmore (2006) shows about the importance for the child's well-being of maintaining a relationship with both parents, either through contact with the non-resident parent or through a shared residence agreement. But the research evidence does not support the courts' adopting an automatic presumption of contact and warns that family situations in all their complexity must be taken into account. Contact 
with the non-resident parent may be beneficial, but it may also be associated with risks to the child's welfare.

\section{Methodology}

The study used a strategy that combined several sources and techniques to produce and collect data (Jick 1979; Morgan 1983) and was carried out at different levels. Statistics from official agencies relating to divorce and gender-based violence were used and information was collected through interviews, consultations with experts, review of court judgements, and direct observation.

One of the problematic issues was defining the sample of women and men involved in the divorce process, because some of the groups that signed the Pact against Gender-based Violence — those in favour of joint custody-wanted the study to be restricted to cases of gender-based violence. ${ }^{3}$ But the feminist associations that were signatories, ${ }^{4}$ claimed that this was not a desirable criterion as a significant proportion of women suffer violence in silence, without legal complaint.

In the end the sample was defined as women and men who dispute the custody of their children in court. ${ }^{5}$ Therefore, cases where parties were able to agree privately over child arrangements are not included in the study.

In the first part of the fieldwork, semi-structured interviews were conducted. A total of thirty interviews were conducted, including seventeen mothers and thirteen fathers who were not related to each other. The criterion for inclusion was that they were involved in litigious cases taking place during the period from 2011 to 2017, from the time the Joint Custody Law was passed in the Community of Valencia until one year after its repeal (when we carried out the fieldwork). We sought to include a maximum diversity of cases in relation to socio-economic level, occupation and number and age of the children involved. ${ }^{6}$

We used the Delphi technique (Linstone and Turoff 2011) to consult two advice communities (Dalkey 1967) or expert groups. Delphi was developed at the RAND Corporation in the 1950s by Helmer, Dalkey and Gordon in the area of national defence, to obtain long-term forecasts. Lindstone and Turoff (2011) point out that the first key characteristic of this technique is the application of questionnaires, with preservation of anonymity in the responses, to a panel of experts, and the second is resending questionnaires focusing on the divergences between the experts, in

\footnotetext{
3 The law does not permit joint custody when gender-based violence is present. Nonetheless, we have identified cases where the courts grant it even when there is gender-based violence in the a family history.

4 The 12 signatory feminist associations (see https://n9.cl/bawlr), included the Federation of Progressivist Women (Federación de Mujeres Progresistas) and the Association of Separated and Divorced Women (Asociación de Mujeres Separadas y Divorciadas), two leading groups championing feminist rights.

5 According to data from the General Council of the Judiciary in 2017, in Spain, cases involving disputes over the custody of children represent $20.1 \%$, compared to $79.9 \%$ where there is mutual agreement.

6 The interview guide, the questionnaires using the Delphi technique and the details relating to the sample of interviewees are available at https://www.uv.es/marijab/ANEXOS.pdf. Accessed 18 June 2021.
} 
several rounds. A key benefit of experts' participation is their ability to participate in a group communication process asynchronously at times and places that are convenient for them. Delphi may be "a method for structuring a group communication process, but it is not a method intended to produce consensus. The number of rounds should be based on when stability in responses is achieved, not when consensus is achieved" (Lindstone and Turoff 2011, 1714) These authors also indicate that Delphi is currently being applied in multiple ways, as support for group decisions or collaborative knowledge systems and collective intelligence.

In this research I worked with two groups of experts. The first, linked to the area of law, in which ten people participated: two judges, two prosecutors, three trial lawyers and three non-governmental organisation (NGO) lawyers. The second, related to professional psychology, included seven people: two forensic psychologists, three professionals from support services in family meeting centres and two from victim support for gender-based violence. Participants in each advice community did not know the identities of the other members and, to ensure that this remained the case, the questionnaires were sent out to them and received by individual email.

What we were interested in was obtaining solid arguments on central issues that we had previously identified at the interview stage.

In preparation for the first round of consultations, we prepared two questionnaires, one for the legal professionals, another for the psychology professionals. The questionnaires include closed and open questions, seeking participants' views on how cases of disputed custody are dealt with. Once the responses were received, they were analysed and compared with each other and the main differences were identified. Based on the meaningful differences, we defined two second questionnaires (again, one for law and one for psychology). On these second questionnaires, the professionals were asked to answer the questionnaire by contrasting their arguments with those given by other participants. As a result of this technique, we did not expect to obtain consensual answers, but we did obtain well-founded statements from experts located in or related to the institutional system.

The last technique used to collect information was direct observations at public services for victims of violence and family meeting points.

The analysis of the empirical material collected through these techniques followed the method of 'grounded theory' (Glaser and Strauss 1967) in which data are interpreted in the light of previous theoretical categories, but also through other categories (themes and sub-themes) that emerge from empirical material and field notes. The analysis is, in short, a process of deconstruction and reconstruction in the form of a pyramid. At the base, we have hundreds of pages of narratives and descriptions, from which the categories that are used to interpret the phenomenon under analysis are extracted.

\section{Some Data on Joint Custody}

The impact of the change in the law has been very significant. In 2009, joint custody accounted for $9.6 \%$ of the total number of court decisions on custody and child arrangements in Spain, and for $9.3 \%$ in the Community of Valencia. In the period 


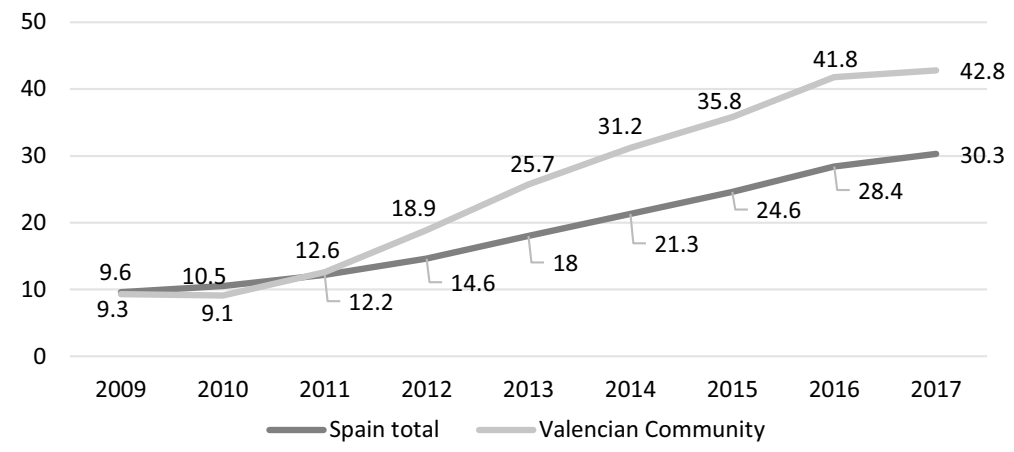

Fig. 1 Proportion of divorces resulting in joint custody in the Community of Valencia and Spain (20092017). Source: Compiled by the author from the General Council of the Judiciary's statistics on annulments, separations, and divorces

considered, the volume of joint custody tripled in Spain, where it rose to $30 \%$ and quintupled in the Community of Valencia, where it reached $42.8 \%$ (Fig. 1).

This growth was at the expense of exclusive maternal custody, which nevertheless still accounted for the majority of child residence arrangements. The average for exclusive maternal custody in Spain fell from $84 \%$ in 2009 to $64 \%$ in 2017, while paternal custody remained constant in the same period, at around $5 \%$ of the total. ${ }^{7}$

If we consider only contested divorces, in Spain, the judgments of shared custody are lower than the values in Fig. 1, around 19\% (data from the General Council of the Judiciary 2016). This implies that, in cases of conflict, judges and prosecutors have been prudent in applying the Supreme Court's opinion indicating that this was the desirable regime for the post-divorce settlement.

The existence of a mixed legal framework in Spain as a whole has generated an asymmetric map around the court rulings on which of the parents (or both) will have custody. In 2017, we can observe that, among the autonomous communities that had their own laws favouring joint custody as the preferred arrangement, most have much higher figures than the national total (Fig. 2): the Basque Country (37\%), Aragon (41.5\%), the Valencian Community (42\%) and Catalonia (47\%). In contrast, in regions such as Extremadura and Murcia they barely reached $16 \%$ and $17 \%$.

\section{Analysis of the Interviews}

We define three moments in analysing the interviews:

\footnotetext{
7 Compiled by the author from the General Council of the Judiciary's statistics on annulments, separations, and divorces https://www.poderjudicial.es/cgpj/es/Temas/Estadistica-Judicial/Estadistica-portemas/Datos-penales--civiles-y-laborales/Civil-y-laboral/Estadistica-de-nulidades--separacion-y-divor cios--INE-/. Accessed 30 Oct 2019.
} 


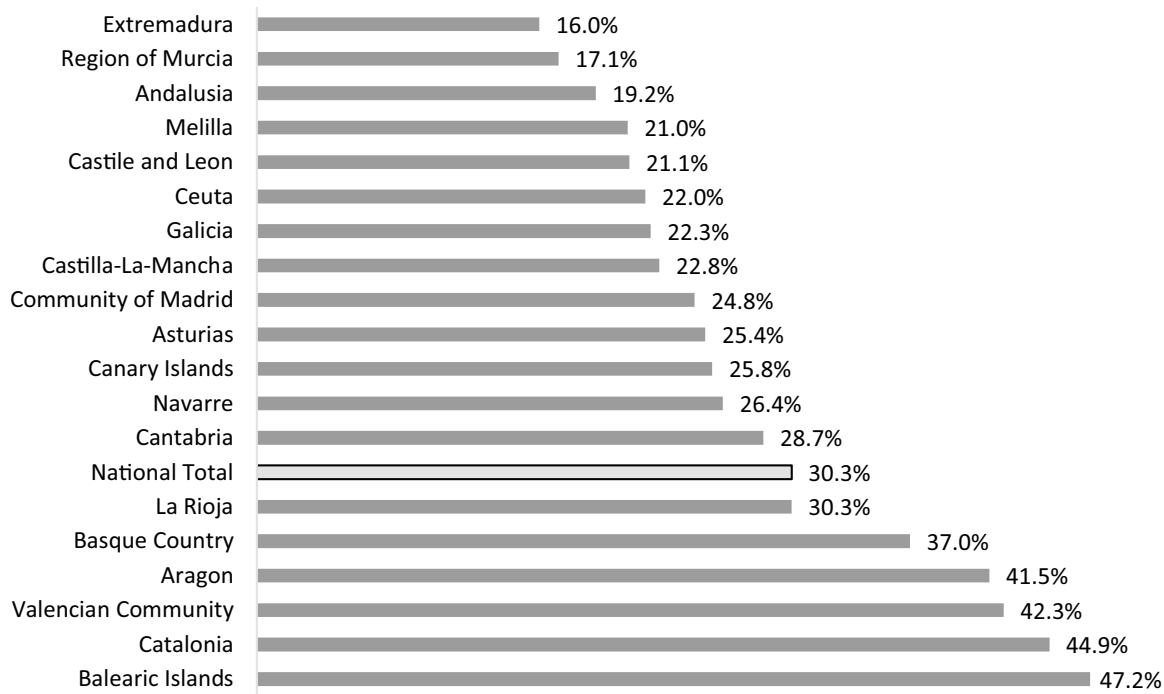

Fig. 2 Joint custody by autonomous community in 2017 (\% of the total number of child arrangements orders). Source: Compiled by the author from the General Council of the Judiciary's statistics on annulments, separations, and divorces

1. The situation before the break-up, focusing on the invisible gender gap in care (Díaz et al. 2016);

2. The judicial process: the incidence of gender-based violence and the mothers' dilemma (Elizabeth et al. 2010), the double standards applied to women and men when arguing about a parent's capacity to care; the court rituals that require short, specific responses and do not allow for the complex processes that are at the root of the disputes to be recounted; and

3. Exploring how the conflict is continued by other means, post-judgment, through economic abuse (Watson and Ancis 2013) and custodial harassment (Elizabeth 2017), leading to what we term motherhood under threat.

\section{First moment: The Impact of Divorce on the Gender Gap}

In the analysis and interpretation of the interviews, we have tried to draw attention to the structural inequalities in couple relationships, which are difficult to perceive, linked to pre-break-up care roles (Díaz et al. 2016; Moreno et al. 2018):

He helped with the housework if I wasn't there, especially in the afternoon, after picking the children up from school. Before the separation began, he became a captain in the national police, working mornings. And I, in my job, I had a rotating schedule, with a week of mornings and a week of afternoons, and, for the sake of the children, I volunteered always to do afternoons, even though I earned less. In the morning, I'd do the housework, took the children to school, brought them home, fed them, and left them with my 
Table 1 Divorces between spouses of different sex in the Community of Valencia, following which spouse pays a compensatory allowance, 2017 Source: Compiled by the author from the General Council of the Judiciary's data

\begin{tabular}{lll}
\hline Total of divorces & 11,191 & $100 \%$ \\
\hline The man pays an allowance to the woman & 907 & $8.10 \%$ \\
The woman pays an allowance to the man & 70 & $0.60 \%$ \\
Neither partner pays an allowance & 10,213 & $91.30 \%$ \\
\hline
\end{tabular}

sister to take them back to school at three. I sacrificed myself because that's how it was, but I think I was stupid, because I could have said "No, I also have the right to finish at three in the afternoon, that's mid-afternoon, and in the summer I can spend the whole afternoon with my children". (Ana)

In her account, Ana describes the dynamics of the couple, her sacrifices and her husband's privileges. With respect to the unpaid work at home, he contributes but the work is not 'his': he takes care of the children while she is away; she has already done the main chores during the morning, alone, when the children are away. With respect to paid work, she changes her shift, so that her wages and her situation in the company are worse, while he is promoted to captain. The gender gap in care impacts on the wage situation of both, but in opposite directions, with a wage penalty for the mother and a bonus for the father (Simonsen and Skipper 2012; Prince Cooke 2014).

Previous sacrifices, lost earnings from caring for children and postponing career development are not compensated for financially after the break-up. Perhaps neither the former spouses, nor the jurists who have to make decisions, nor even the women themselves who have been involved in these situations are aware that the mother's surrender involves an economic and professional impact on them. Nevertheless, it impacts in the short term and in the immediate present when their personal sacrifices occur. And it impacts on their future, on their professional development and their retirement pension. This lack of recognition of the economic consequences of the mother's surrender can be seen in the fact that judges rarely make use of an existing legal tool to compensate for the possible worsening of the economic circumstances that separation or divorce may cause for one of the spouses, which is the 'compensatory allowance'. Only in $8.1 \%$ of divorces does the man pay the woman a compensatory allowance (see Table 1). In $91.3 \%$ of cases there is no compensatory pension.

Furthermore, marital break-up itself can entail new economic costs for both members of the former couple: (1) from losses due to the division of assets; (2) because services for the upkeep of the home itself, previously assumed by the couple, now have to be paid by a single person; and (3) the costs of the legal process itself, including paying for lawyers and expert opinions. Figure 3 summarises the economic costs that can come with a divorce process, impoverishing those involved.

But if women's former contributions to the family are not recognised, women can be penalised twice over. First, this is due to the lack of economic compensation for their past sacrifices and second, because they have to face divorce in a worse off economic situation, having less time at their disposal than their ex-partners who, moreover, delegate care to other women (mothers, sisters, grandmothers, girlfriends). 


\begin{tabular}{|l|l|}
$\begin{array}{l}\text { While living as a couple, a gender gap concerning care is established: } \\
\text { turning down a promotion or reducing one's workload to have more } \\
\text { time to devote to care has an impact on income with immediate effect, } \\
\text { but also has an effect in the long term. }\end{array}$ & $\begin{array}{c}\text { It is } \\
\text { usually } \\
\text { invisible }\end{array}$ \\
\hline $\begin{array}{l}\text { DIVORCE-RELATED FACTORS } \\
\text { Aspects with major impact: each } \\
\text { partner ends up with only half the } \\
\text { assets as a result of their division. }\end{array}$ & $\begin{array}{l}\text { All the housing expenses that were previously } \\
\text { shared as a couple must be faced alone (rent, } \\
\text { mortgage, supplies). }\end{array}$ \\
$\begin{array}{l}\text { Aspects specific to divorce } \\
\text { proceedings: trial fees (lawyers, } \\
\text { experts, detectives, etc.) }\end{array}$ & $\begin{array}{l}\text { Child maintenance (in case of exclusive } \\
\text { custody). } \\
\text { Further expenses (vary, difficult to determine). } \\
\text { Compensatory allowance (only in } 8 \% \text { of cases). }\end{array}$ \\
\hline
\end{tabular}

Fig. 3 Summary of the economic factors involved in divorce. Source: Compiled by the author from interviews

\section{Second Moment: The Legal Process}

The myth of Hera, the vengeful goddess who punished Zeus, his lovers, and their children, is a stereotype that remains deeply rooted in our culture. And this label of the woman who would do anything for revenge sometimes leads real women to show less willingness to engage with a legal system they see as working against them. Rodríguez and Bodelón in their ethnographic work in Barcelona's gender violence courts observe that

in general, women were seen and heard to be demoralised, frustrated, and/or disappointed with the way the criminal system was working, some even considered that everything they did "had no point"... for a wide variety of reasons, they had a certain urgency to finish with everything involved with the complaint they had filed, in order to get "a little peace and quiet" $(2014,113)$.

In Spain, $65 \%$ of cases of gender-based violence are not reported, ${ }^{8}$ and therefore, from the outset, they are invisible to the Family Courts where the former partners fight for custody.

\footnotetext{
8 "[O]f the total number of women who have suffered physical or sexual violence from one of their partners during their lives, or have been afraid of one, $26.8 \%$ reported what happened to the police, and $1.7 \%$ went to court directly to file a complaint. Given that $6.4 \%$ of women do not testify in court, there are still $65 \%$ of women who have been victims of physical or sexual violence, or fear of them, who neither the police nor the courts have any knowledge of" (Ministry of Health, Social Services and Equality 2015, 175).
} 
So look, you just don't know what to do... They were going to say that I was taking the child away from him... and in fact that was the argument he used in the family court. And it worked out quite well for him... The typical mother... who wants revenge, taking the child away from you and all that. Well, that feeds the myth of the vengeful woman or that... besides, I don't know where he got it from, because it was me who filed the lawsuit, "so I've gone off with another woman and then she feels rejected and that's why she wants to take my children away from me". I'm sorry, but I'm the one who said enough! (Virginia)

In custody disputes, the incidence of gender-based violence is varied. It can be either explicit or implicit. But when a complaint is made in the criminal courts, if there is a divorce trial pending, this generates fairly generalised suspicions, which have led the group of experts from the General Council of the Judiciary to indicate:

Reviewing a number of sentences handed down by the Criminal Courts and Specialised Sections of the Provincial Courts calls attention to that the fact that the victim's being involved in separation or divorce proceedings is used as a criterion to undermine her credibility, despite the fact that... it can be seen that in cases of separation there is an increased risk that the woman may suffer an attack. ${ }^{9}$

In the courts, when such a bias occurs, it re-victimises women, because it is precisely when a woman files for divorce and there is a history of gender-based violence that her risk of suffering violence increases (Hayes 2017). The General Council of the Judiciary expert group warns that there should not be any deliberate misconstruction, because these are not false allegations.

October was the provisional hearings. You arrive there trembling, and I didn't report the gender violence for fear of not being believed, of being thought to be using it for the separation... as we women are so manipulative and carry it in our genes. You have this fear that you will not be believed and you also doubt that it is happening to you: "How can it be that, with my training, I'm in this situation and have not been aware of what was happening?" I blamed myself. I blamed my women friends who were psychologists and social workers. But I didn't tell them everything that was happening to me, of course. I covered it up, you're ashamed. (Estela)

They told me that as long as I was breastfeeding, I'd have custody... and then in the gender-violence trial, they asked me how I'd endured it for so long if I was having such a bad time. (Virginia)

The mother is faced with the dilemma of reporting the negative consequences that the father's visits have on their children, with the fear of being disbelieved and accused of animosity towards her ex-partner (Elizabeth et al. 2010). They fear being construed as hostile and that their statements will have a negative impact on psychological reports or the outcome of the trial. Harrison (2008) asks whether women are

\footnotetext{
9 Practical Guide to Law 1/2004 On Comprehensive Protection against Gender-based Violence General Council of the Judiciary 2016, 202.
} 
being relentlessly hostile or appropriately protective. They need to tell their story to protect their children from joint custody.

I saw negligence in care: lack of hygiene, a lot of it. Once I saw a cigarette burn, due to negligence, that is, I am not saying that he burned her, but he was smoking. So I told him, I say: "Hey, what's this?" And he replies: "I was with some friends, and she came running and got burned". Yeah, man, but it's a cigarette burn and she came crying. (Celia)

For a month now, he [a four-year-old boy] has been more accepting [going to spend the night at his father's]. But he asks me: "Am I sleeping here with you tonight?" A friend told me: "Well, he'll be saying the same to his dad, because children are very manipulative". But for your son to tell you in tears, "Mummy, don't put me in pants to go to Daddy's house, put my nappy on, because Daddy says that otherwise I'll pee on the floor". And the cost of it! He was using nappies until he was three. And of course, his dad was blackmailing him with "If you wet my bed..." Typical of the things he'd say to me too. (Virginia)

In our study, we observed that the courts provide almost no protection for children when their mothers report gender-based violence. Only $9.1 \%$ have any protection for children. ${ }^{10}$ Reyes Cano $(2015,214)$ points out that, according to her research, $96 \%$ of children were present when their mother was assaulted by their father, thus establishing violence in their lives on an everyday basis. Thirty per cent witnessed beatings, kicking, hair pulling, pushing or saw their father grabbing their mother by the throat, the injuries caused, etc., and $96 \%$ witnessed mostly insults, humiliation, death threats, breaking objects, perceiving the tension and threat in the environment, as well as the suffering of their mother. It is worth noting that $36 \%$ of the cases suffered direct aggression.

In the following testimony, we observe how the lack of coordination between family courts and gender-based violence courts can exacerbate the daily dilemma of mothers with children living with gender-based violence (Lindauer 2012):

If I had her [the girl], he was calm. If he had her, he thought I was going off with someone else. And then when I reported the GBV [she was already in divorce proceedings], the GBV judge told me "until the trial is over, don't let him have her". He became obsessed because he didn't see the girl for a while and I wasn't respecting the contact arrangements. Then, a month and a half later, because the trial was delayed for five months, well then I let him see her, through my sister. (Luisa)

Anxiety also arises around how to explain to children what is happening. Neither their mother, nor their father, nor any public service tells them what is happening in their family or what will happen to them in the legal proceedings.

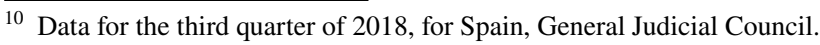


If the child comes home one day in distress, saying "Let's go to dad's house because I have to take him some drawing or other" ... "Well, sweet, we can't go because dad's probably out shopping" ... "No, I don't think so. Let's go to dad's house" ... And you make up a story so that you don't have to explain to him why he can't go... Simply because he's a three-and-a-half-year-old boy, no, and then the next day he comes back and says, "No, dad told me that it's you who doesn't want to see him and that there's a restraining order. And that's why we couldn't go to his house," you know? (Yolanda)

Children are not just witnesses but, as the law now recognises, direct victims, even though the phrase 'I didn't do anything to the child' continues to resonate in the courts' corridors:

I've had him three months in a wheelchair, and a month and a half on crutches. Now he's fine. Physically, he has nothing-he's had MRI scans, he's been in hospital... And the only turning point, and I don't want to say it because I'm not objective, was when he started going to sleep at his father's house. One day he got out of school and the next day he couldn't walk. The pain was real, and he was crying day and night. But the paediatrician told me, "I don't know why he's not walking". Now he's fine. The psychologist has been with him and she made him flip the way he was thinking. (Verónica)

Children may also be abused as a means of exercising power and control over women (Bancroft and Silverman 2002; Hayes 2012 and 2017). But in addition to possible physical assaults, the children are also subjected to micro-violence, such as being deprived of their own belongings:

His stuffed toys... they're at his [father's] house, and he doesn't let him take anything from here. Because he says they are his things [the father's]. Of course the boy comes back from school with a picture he likes and says, "Mum, keep it here". Or they give him a book and he says, "We've got more books here, let's keep it here". But you know that because he's signed him up for art, he'll want all the drawings from the class, because he's paying for it. They're subtle things, but he's not free to have his own things and take them and bring them where he wants. You can see that your child resents it, of course-it's his stuff! (Adela)

In the interviews, the fathers do not usually admit that they use violence. They even find excuses for the judges when they are arrested or are subject to a restraining order, blaming it on media pressure:

With so much news about a judge being clobbered when a woman is killed and he hadn't issued restraining orders, you understand that, because of media pressure, the judge gives you a restraining order, just in case something happened, even though you've done nothing. And, come the trial, that leaves an element of doubt as to whether you are an abuser, even if it was a false accusation. (Juan) 
On a few occasions they do acknowledge that they use violence:

When I saw the civil guards, my daughter who was three was next to me, and my reaction was that, I told my wife: "If you speak to me like that again in front of my daughter, I'll cut your throat and throw you in a hole". That's what I told her, I admit it. (Ferran)

The father-child bond is a fundamental element in culture, even in the cases of conflict that we are considering, but on some occasions, such as those investigated here, it can end up being painful and harmful to the child.

\section{Stereotypes of Mothers and Fathers in the Divorce Courts}

The way that interviewees reconstructed their relationship with the legal system reveals how gender stereotypes operate. Fathers feel singled out by society as perpetrators of violence, experiencing it as a stigma. According to them, the laws and the media favour women, putting men at a disadvantage before the law. NavarroFletcher and Díaz-Martínez, members of the research team, point out that the men interviewed "perceive that, regardless of the court result or of their various encounters with the system, because they are men, they are already unlikely to be listened to, and may even be viewed, by default, as aggressors" (Navarro-Fletcher and DíazMartínez 2020, 119). Nevertheless, with a few exceptions, when asked about their case, they say that they have been lucky because they were given a good judge and are quite satisfied with the court result. We also noticed that they repeatedly gave a positive assessment of their relationship with the police even in cases where they had been arrested. A good example of this is the following testimonies:

There are false reports all the time; there are many men who are fucked up because of that... Thank God, I was lucky. (Bernardo)

The trial, yes, I think it was fair. Even though the media criminalise men, for me the trial, in my opinion, was fair. (Lorenzo)

Lorenzo also tells us what happened after a call from his ex-wife to the police:

The police went back and forth, and the inspector said, "Go, take off your vests, nothing's happening here". And he turns to me and says, "You're going to have to come with us, lad... but you should know that if it's a false report, then you can report it. (Lorenzo)

In contrast, Samper-Gras, a member of the same research team, recounts that "there is an accepted social image that mothers always get sole custody in court" (Samper-Gras 2020,147), which as we have seen, is no longer the case due to the notable growth in joint custody. And, this supposedly positive (but distorted) image of women's position in court is, we are told, supplemented by a legal discourse that portrays them as "lying and ambitious women", playing out a fake parental alienation syndrome (PAS) (Boyd 2010), in order, supposedly, to break the bond between the children and their father, manipulating emotions in order to hold onto the marital 
assets. But, unlike men, they express great discomfort at the treatment they receive in the courts:

Based on my experience of what happens in the courts, I have seen that we are not credible. They [men] put on the faces of good people, little lambs, and we are always the ones questioning them, we always have to prove everything, and when it's psychological violence, it's very difficult to prove, unless you have a great professional in front of you who can detect it from the four sentences you say to her. (Estela)

For a lot of the time they kept insisting: "These are false accusations for your own ends... of course, you don't want it [custody] to be joint, what you want..." And I can tell him, look, "joint" is going to be a blessing compared to the contact arrangements I have now. At least for me. As for the boy... No! because as soon as he started to spend nights with him, he began to protest... And I was speaking from the heart: all this about "joint" and it's so much rubbish... what do you mean that we don't want "joint"?... Look, what I want is to live in peace... Those were two horrendous years. (Cristina)

They describe how, in their experience, gender stereotypes condemn them, because it is always women who are accused of false reporting and PAS (Rodríguez and Bodelón 2014). In our review of divorce orders, PAS is mentioned several times as an argument for denying a woman custody. The words 'manipulation', 'instrumentalisation', and 'parental interference' also appear as cover phrases to avoid the term PAS, while serving the same purpose, namely secondary victimisation of women.

As the accounts show, children can certainly get caught, either in the crossfire of accusations and contempt or by aggression coming from one side only, when one parent maintains a reasonable position and the other does not. But words of disdain and disparagement do not generally lead to a break with the minor. In any case, recommending or ruling against a child's wishes is questionable since, at the very least, the courts should take steps (with psychological experts, for example) to find out how the child is doing, what their reasons for refusing contact with a parent are and the stressful situations they may be suffering.

Court rituals make it hard to find clarity, dismantle prejudices, or tell about the processes experienced. Only fragments can be recounted, and testimony about the problems ends up being superficial. This is aggravated when the conflict is recurrent, because at each trial the parties have to adjust to what they are asked in the new situation, as if they were discrete, separate situations, as if they were not part of the same story.

\section{A Parent's Ability to Care}

In deciding on a custody regime, the legislation states that the court must take into account whether both parents provided care before separation. For this reason, in many judgments we observe the expression 'the parent's ability to care'. This ability 
is interpreted in a biased manner by the courts, depending on whether it applies to a man or a woman (Eichler 1991; Díaz et al. 2016). In the case of men, it is a potential ability and implies a second chance. In the case of women, the care they have given is evaluated so that they have to prove that they are good mothers. Some of the experts consulted pointed out:

a. Due the very nature of social beliefs, mothers are thought to have a greater capacity for care than fathers, though (surprisingly) this has no particular impact on the allocation of custody and care to the mother in some courts, as they (increasingly) prioritise joint custody regardless of the child's best interests. This is a reality, attributable to most judges' and prosecutors' lack of a gender perspective. (Family Meeting Point)

b. There is no doubt that judges, like other people in our society, are conditioned by patriarchal ideology or an ideology of male supremacy and are much more indulgent in assessing men's capacity for care than women's. They take it for granted that care belongs to women and that fathers can do it too, even if they have never done so prior to the break-up. (Lawyer, a woman who specialises in family law)

Both opinions indicate a double standard (Eichler 1991) because on the one hand women are considered to be the carers, but in the end, the decisions may favour men because it is assumed that the tasks of raising children can be taken up by anyone.

\section{Third moment: The Vicious Circle of Economic Abuse}

One part of the conflict between the former couple is expressed through the maintenance allowance. Money has been considered by classical economists as the general equivalent of commodities, but Zelizer (2011) notes that not all money has the same social meaning. In fact, child maintenance or alimony involves a transfer of money from one parent to another to cover the expenses of the children they have in common, so it has a strong symbolic content. This seems to enable both parents to exercise a particular type of control over this money, which belongs to the children.

When there is exclusive maternal custody, the fathers retain their role as economic providers because they are the ones who pay the allowance, but they lose presence and power. This feeling increases when there are new partners, a feeling of a displaced father emerges.

They met an intruder, that they did not know who he was, and were forced to accept him, for good or ill. In the same house, in the same room I was in. She'd replaced one piece with another. (Dimitri)

The loss of power and the feeling of exclusion are perhaps the factors that explain the fact that most joint custody is requested by fathers. There has also been, as Cozzolino and Williams (2017) point out, a change in social expectations whereby women are seen as more economically solvent than in the past and men are expected to become more emotionally involved. Such changes would mean women being expected to be more involved in economic support and men in the care. 
In our research, however, several women have pointed out to us that their former partners have camouflaged their income in order to reduce the maintenance, though they then compensate with direct gifts to their children. Kristin Natalier notes that there is "post-separation economic abuse related to child support, which reflects and reproduces the gendered social order" (Natalier 2018, 122). Economic abuse, from our perspective, consists of limiting payments with the aim of regaining some of the control lost in a social space to which the fathers no longer belongs, such as, that of the new family that includes the mother, the children and perhaps, other new members. We have observed that an invisible war of attrition is being waged, always framed within certain limits, so that it remains within the space of everyday life. When too many tensions accumulate, we move from economic abuse to open conflict in the legal sphere. There are games, played with a knowledge of how much to tighten the grip and then loosen up and be more conciliatory, and then tighten again, until the situation becomes too much and ends up with a lawsuit in the courts.

I've managed to get it ordered by the court but he keeps failing to pay, so the fear continues. The payment for August still hasn't come through, as of now, as well as 200 euros that he hasn't paid us. I mean... but there comes a time when I just want to be calm, so if you don't come [to pick up the child], if you tell me on the day itself, I'll make the changes, even if it's not my turn and he should be relying on his own people... you know, going to law over small things is exhausting. (Estela)

He breaks part of the agreement and, in addition, Estela is afraid and intimidated; he is physically very big and threatens her verbally. She can go back to the courts, but as she says, it "is exhausting". Estela prefers to seek informal arrangements, even if they are temporary. The situation described here was repeated in several other interviews.

The findings from our study demonstrate that the court order is valued by women, because it is an objective ruling established by an authority that allows them to persuade their ex-spouses to follow externally established regulations. And if the men do not keep to them, they can go to court to have the order enforced. Nonetheless, the other party knows that the cost to her of enforcing it is high, because it involves a complaint, within the courts' timetable, along with the stress of repeated legal proceedings. There are power games in the gap between what is established by the order and complying with it, and these are dependent on what is at stake in complying or failing to comply. There is an emotional and economic cost in turning a blind eye and there is an emotional and time cost in reporting non-compliance. As Sullerot points out, "time is perhaps the most pressing and most important dimension in a woman's life" (Sullerot 1988, 389), and hunger for time is hugely significant in the decisions that women make. 


\section{Motherhood under Threat}

María met Pedro in a pub and they began to see each other, from time to time, until they ended up living together in María's house. Pedro was 11 years younger and she was delighted when he proposed that they should have a child together.

I was as happy as Larry. I got pregnant right away. Of course, I had a risky pregnancy: at forty... The truth is that I enjoyed it very much. But then he started to disappear. He and his family had a bar, and it started that he was never in a hurry to come home. He was always doing his own thing, with these guys, with those. I'd wake up and see that he wasn't there; at three in the morning, at four. I was his secretary, his diary, his cook, his ironer....

First he was insulting me, that I was hysterical, embittered, unhappy, that I wanted to ruin his life too. And he threatened that if I made any decision, I'd get minimum access to my daughter. I kept on putting up with it, kept thinking that this can be solved. Of course, the disconnection's growing. He just sees you as a row waiting to happen, to throw things in your face. Then, he went and punched me in the glasses and didn't even stop to say, "Oh, I'm sorry. Did I hurt you?". He gave me the feeling of... contempt. Other times, yes, he'd say to me, "I'm going to change, forgive me". Once he gave me a push and hit me against the wall. At that moment I saw my daughter in the doorway. And that's when I said: "Never again. It's over" [without reporting him]. (María)

In the interview she stresses that it was seeing her daughter there that led her to make the decision.

Once I'd made the decision, it was as if all the suffering had gathered around me, and I needed to get out of there. Out of the door, over the balcony, wherever I could. (Maria)

Boyd (2010) analyses the dilemmas faced by mothers who suffer violence and points out that among the factors they weigh up when deciding whether to stay or leave, the responsibility to protect their children plays an important role. But then, their experiences with the courts can re-victimise them. They find it difficult to move between courts with different jurisdictions - criminal, family - that have no coordination and insufficient gender training to understand the risks the women and their children are trying to escape from. Watson and Ancis indicate that "because a woman has left an abusive relationship does not mean that the abuse has subsided" (2013, 167).

In a relationship where there is abuse, conflict is a constant because through it one partner maintains coercive control, which Samantha Jeffries defines as "a pattern of on-going intentional domineering tactics employed by (usually) male perpetrators with the intent of governing their female victim's thoughts, beliefs or conduct and/or to punish them for resisting their regulation" (Jeffries 2016, 1). And to avoid negative consequences, such as insecure attachment in younger children, support should be provided to mothers who suffer violence and the sooner, the better (McIntosh 
et al. 2019). Intervention is needed to avoid far-reaching consequences over time, such as the vicious circle of economic ause and "custody stalking" (Elizabeth 2017).

Motherhood under threat can be the result of constantly questioning the mother's authority through all kinds of mechanisms, which end up forming a vicious circle creating never-ending conflict after the divorce decree. The failure to comply with court decisions becomes chronic, making the process of separation endless and Kafkaesque. Women are threatened in many ways, put under financial pressure and fear for their children's emotional well-being and physical safety while they are in their father's house. We have seen that parental rights are rarely suspended after a divorce, even when violence occurs. Mothers, spending more time with their children, make decisions without consultation, due to lack of time or difficulties in communicating with their ex-partner. Fathers resent this as an infringement of their parental authority or as a limitation of their patriarchal decision-making power. The mother's status or 'motherhood' is threatened because almost all the decisions she makes are questioned in front of the children, by a father who now gets involved and gives his opinion about whether or not they can attend an activity, birthdays, how to celebrate a First Communion, camps, holidays, visiting the dentist, etc. These decisions were part of the job of childcare, which he did not usually take responsibility for before.

In the worst cases, there are also emails with accusations and calls at any hour. Added to these are emails or texts to children involving emotional blackmail, which produce suffering and are a form of psychological violence. Another way fathers may convey their questioning of maternal authority is to change their mind about agreements. Disputes about extra expenses, from medical or dental expenses to social and cultural activities, games and sports, are also common.

Another tactic in this area, which both mothers and fathers report, is the marking of territory, controlling or preventing the children's communication with the other parent during the whole time they are visiting their home.

Psychological damage is not as immediately visible as physical damage. And, although we have described here how it appears in the post-divorce stage, its roots must be sought much further back.

In short, caring for children involves all kinds of difficulties, across multiple dimensions, because care is physical, emotional, psychological, intellectual and social at the same time. But the power games related to parental authority stand in the way of care for and the well-being of the children, and put them in a very vulnerable situation.

\section{Conclusions}

In this study, we have highlighted that our research focused on special cases, as only $20 \%$ of children's residence arrangements are the subject of dispute. Therefore, it is important to emphasise that many debates omit this fundamental variable: the degree of conflict between the partners in the couple, before, during and after the break-up. The legal approach must be specific to each situation. Here we show the complexity that exists in contested divorces where there are children, from a sociological approach and taking the mothers and fathers as the main interlocutors. 
We have tried to reveal aspects that remain in the shadows and that are not evident or drawn attention to in the legal proceedings. No general position for or against joint custody is proposed here, but we do give several warnings about the possibility of cases of hidden gender-based violence, with all the consequences that this has for women and children. In addition, we indicate the possibility of producing gender bias, such as the double standard described (Eichler 1991; Díaz et al. 2016), whereby the pre-break-up care provided by mothers and fathers is assessed differently by the courts.

In addition, we have observed that the job of caring, while the couple was together, involves an invisible contribution by women to the family, with generally negative repercussions on their personal income. And this situation is not recognised in economic terms in divorce proceedings. Divorce itself entails significant economic costs and during the proceedings, women must balance the roles of providing economically and caring, often alone. Institutions' gender blindness to the economic value of care and its impact on earnings during the life of a couple is a further vulnerability added to women's situations in child custody cases.

The lack of social consensus on how best to protect the child's best interests was no obstacle to promoting joint custody in Spain. The data presented here show its rapid progress, but no significant correlation in terms of shared parental responsibility for care (Fernández Rasines 2016). Custody and care should come together, and this does not mean either parent giving up contact, which can occur through an appropriate contact arrangement.

The voices of children must be listened to and greater attention paid to women's testimonies, even when they have not reported violence, putting aside the stereotypes that, to this day, present them with the dilemma of remaining silent or being socially labelled.

The principle of the child's best interests appears repeatedly in legal rhetoric. However, the needs of children are neglected because the belief that they may be manipulated deprives them of their right to be taken into account. Furthermore, the courts' timetables and rituals do not accommodate the possibility of revealing what is really happening in the case of a child who does not want to have contact with a parent.

Divorce is not the end of the former partners' bond when there are children in common. Gender analysis allows us to observe, in addition, that when there is violence, it is perpetuated through a strategic use of parental authority. Men who have previously been uninterested in day-to-day decisions exert an obsessive and aggressive influence on micro-decisions that affect daily life because parental authority is a right that supports them. We have described the vicious circle that comes into play over child maintenance and micro-decisions, although the fathers try not to go too far because they can be reported. Even so, appeals to the courts are numerous. Motherhood comes under threat in these power games that constantly challenge it.

Social pacts such as the one that gave rise to this study can promote the visibility of realities that legal formalities systematically filter out because as with any cultural change, incorporating the gender perspective into institutions requires time and, above all, social and political alliances, both inside and outside the judiciary, with a real commitment to equality. Joint custody may be a good to aspire to but we do not 
live in an ideal world, and we must advance by improving shared parental and public responsibility, achieving a better connection between custody and care, to improve the real world.

Acknowledgement I would like to thank Capitolina Díaz-Martínez for her major contribution to this research. We collaborated in coordinating this study, which was financed by the Valencian government within the framework of the Valencian Pact against Gender-based Violence.

Open Access This article is licensed under a Creative Commons Attribution 4.0 International License, which permits use, sharing, adaptation, distribution and reproduction in any medium or format, as long as you give appropriate credit to the original author(s) and the source, provide a link to the Creative Commons licence, and indicate if changes were made. The images or other third party material in this article are included in the article's Creative Commons licence, unless indicated otherwise in a credit line to the material. If material is not included in the article's Creative Commons licence and your intended use is not permitted by statutory regulation or exceeds the permitted use, you will need to obtain permission directly from the copyright holder. To view a copy of this licence, visit http://creativecommons.org/licen ses/by/4.0\%.

\section{References}

Alascio Carrasco, Laura. 2011. La Excepcionalidad de la Custodia Compartida Impuesta (art. 92.8 CC). InDret, 2 .

Bancroft, Lundy, and Jay Silverman. 2002. The Batterer as Parent: Addressing the Impact of Domestic Violence on Family Dynamics. Thousand Oaks, CA: Sage.

Boyd, Susan B. 2010. Autonomy for Mothers? Relational Theory and Parenting Apart. Feminist Legal Studies 18: 137-158.

Campo Izquierdo, Ángel L. 2009. Guarda y Custodia Compartida: ¿Se debe Condicionar su Concesión a que exista un Informe Favorable del Ministerio Fiscal? Diario La Ley 7206: 3.

Conde Pumpido García, L José. 2011. Ley Valenciana de Custodia Compartida. Revista De Treball, Economia $i$ Societat 62: 1-30.

Cozzolino, Elizabeth, and Christine Williams. 2017. Child Support Queens and Disappointing Dads: Gender and Child Support Compliance. Social Currents 4 (3): 228-245.

Cruz Gallardo, Bernardo. 2012. La Guarda y Custodia de los Hijos en las Crisis Matrimoniales. Madrid: La Ley.

Dalkey, Norman C. 1967. The Rand Corporation, Santa Monica, California. https://apps.dtic.mil/sti/pdfs/ AD0660554.pdf

Díaz, Capitolina, Marcela Jabbaz, Empar Aguado, and Lydia González 2016. Las Brechas de Género: Brecha de Cuidados, Brecha Salarial y Brecha de Tiempo Propio. In Brecha Salarial y Brecha de Cuidados, ed. Capitolina Díaz and Carles Simó. Valencia: Tirant lo Blanch.

Eichler, Margrit. 1991. Nonsexist Research Methods: A Practical Guide. London: Routledge.

Elizabeth, Vivienne. 2017. Custody Stalking: A Mechanism of Coercively Controlling Mothers Following Separation. Feminist Legal Studies 25: 185-201.

Elizabeth, Vivienne, Nicola Gavey, and Julia Tolmie. 2010. Between a Rock and a Hard Place: Resident Mothers and the Moral Dilemmas They Face During Custody Disputes. Feminist Legal Studies 18 (3): 253-274.

Fehlberg, Belinda, Lisa Sarmas, and Jenny Morgan. 2018. The Perils and Pitfalls of Formal Equality in Australian Family Law Reform. Federal Law Review 46 (3): 367-396.

Fernández Rasines, Paloma. 2016. Parentalidad: Leyes, Normas y Prácticas Parentales. Quaderns-e De L'institut Català D'antropologia 21 (2): 119-134.

Gaitán Muñoz, Lourdes. 2018. Los Derechos Humanos de los Niños. Ciudadanía más allá de las "3Ps". Sociedad e Infancias 2: 17-37. https://doi.org/10.5209/SOCI.59491.

Gálvez-Muñoz, Lina. 2016. La Economía y los Trabajos de Cuidados. Madrid: Deculturas. 
General Council of the Judiciary. 2016. Guía Práctica de la Ley 1/2004 de Protección Integral contra la Violencia de Género. http://www.poderjudicial.es/cgpj/es/Temas/Violencia-domestica-y-de-genero/ Actividad-del-Observatorio/Guias-practicas/Guia-practica-de-la-Ley-Organica-1-2004--de-28-de-dicie mbre--de-Medidas-de-Proteccion-Integral-contra-la-Violencia-de-Genero--2016-. Accessed 30 Oct 2019.

Gilmore, Stephen. 2006. Contact / Shared Residence and Child Well-being: Research Evidence and its Implications for Legal Decision-making. International Journal of Law, Policy and the Family 20 (3): 344-365.

Glaser, Barney G., and Anselm Strauss. 1967. The Discovery of Grounded Theory Strategies for Qualitative Research. Chicago: Aldine.

Hacker, Daphna. 2008. A Legal Field in Action: the Case of Divorce Arrangements in Israel. International Journal of Law in Context 4 (1): 1-33.

Harrison, Christine. 2008. Implacably Hostile or Appropriately Protective? Women Managing Child Contact in the Context of Domestic Violence. Violence against Women 14: 381-405.

Hayes, Brittany E. 2012. Abusive Men's Indirect Control of their Partner During the Process of Separation. Journal of Family Violence 27: 333-344.

Hayes, Brittany E. 2017. Indirect Abuse Involving Children During the Separation Process. Journal of Interpersonal Violence 32 (19): 2975-2997.

Hunter, Rosemary. 2015. More than Just a Different Face? Judicial Diversity and Decision-making. Current Legal Problems 68 (1): 119-141.

Jabbaz-Churba, Marcela and Díaz-Martínez, Capitolina. 2020. Menores en Disputa. Custodia, Visitas y Patria Potestad en la Comunidad Valenciana. Valencia: Tirant lo Blanch.

Jeffries, Samantha. 2016. In the Best Interests of the Abuser: Coercive Control, Child Custody Proceedings and the "Expert" Assessments that Guide Judicial Determinations. Laws 5 (1): 14.

Jick, Todd 1979. Mixing Qualitative and Quantitative Methods. Triangulation in Action. Administrative Science Quartely, 24 (4): 602-661.

Lindauer, Margo. 2012. Damned If You Do, Damned If You Don't: Why Multi-Court-Involved Battered Mothers Just Can't Win. American University Journal of Gender, Social Policy \& the Law 20 (4): 797-822.

Linstone, Harold A., and Murray Turoff. 2011. Delphi: A Brief Look Backward and Forward. Technological Forecasting and Social Change 78 (9): 1712-1719.

McIntosh, Jennifer, Evelyn Tan, Alytia Levendosky, and Amy Holtzworth-Munroe. 2019. Mothers' Experience of Intimate Partner Violence and Subsequent Offspring Attachment Security Ages 1-5 Years: A Meta-Analysis. Trauma, Violence, \& Abuse, 1-15.

Ministry of Health, Social Services and Equality. 2015. Macroencuesta de Violencia Contra la Mujer. https:// violenciagenero.igualdad.gob.es/violenciaEnCifras/estudios/colecciones/pdf/Libro_22_Macroencue sta2015.pdf. Accessed 18 June 2021.

Moreno-Colom, Sara, Marc A. Cosp, and Vicent B. Català. 2018. La Masculinización del Tiempo Dedicado al Trabajo Doméstico Rutinario. Revista Española De Investigaciones Sociológicas 163: 41-58.

Morgan, Gareth. 1983. Beyond method: Strategies for Social Research. Los Angeles: Sage.

Natalier, Kristin. 2018. State Facilitated Economic Abuse: A Structural Analysis of Men DeliberatelyWithholding Child Support. Feminist Legal Studies 26: 121-140.

Navarro-Fletcher, Viktor and Capitolina Díaz-Martínez. 2020. La Paternidad en Divorcios Litigiosos. In Jabbaz-Churba and Capitolina Díaz-Martínez, op.cit., 117-149.

Picontó Novales, Teresa. 2010. La Custodia Compartida a Debate. Madrid: Dykinson.

Prince Cooke, Lynn. 2014. Gendered Parenthood Penalties and Premiums Across the Earnings Distribution in Australia, the United Kingdom, and the United States. European Sociological Review 30 (3): 360-372.

Reyes Cano, Paula. 2015. Menores y Violencia de Género: de Invisibles a Visibles. Anales De La Cátedra Francisco Suárez 49: 181-217.

Rodríguez Luna, R., and E. Bodelón González. 2014. Mujeres Maltratadas en los Juzgados: la Etnografía como Método para Entender el Derecho «en Acción». Revista De Antropología Social 24: 105-126.

Salas Carceller, Antonio. 2020. Custodia de Menores: Aspectos Relevantes de la Custodia en los Procesos de Familia. Análisis Normativo y Jurisprudencial. Coruña, España: Colex Reader.

Samper-Gras, Teresa. 2020. La Voz Desprestigiada de las Madres. El Caso de los Juicios por Custodia. In Marcela Jabbaz-Churba and Capitolina Díaz-Martínez, op.cit., 150-171.

Simonsen, Marianne and Lars Skipper. 2012. The Family Gap in Wages: What Wombmates Reveal. Labour Economics 19 (1): 102-112.

Sullerot, Evelyn. 1988. Historia y Sociología del Trabajo Femenino. Barcelona: Península. 
Tobío, Constanza. 2012. "Cuidado e Identidad de Género. De las Madres que Trabajan a los Hombres que Cuidan”. Revista Internacional De Sociología 70 (2): 399-422.

Watson, Laurel B. and Julie R. Ancis. 2013. Power and Control in the Legal System: From Marriage/Relationship to Divorce and Custody. Violence Against Women 19 (2): 166-186.

Zelizer, Viviana. 2011. El Significado Social del Dinero. Buenos Aires: Fondo de Cultura Económica.

Publisher's Note Springer Nature remains neutral with regard to jurisdictional claims in published maps and institutional affiliations. 